\title{
Historical Value At Risk As A Predictive Risk Method For The Investors: Causality Analysis Related To US Dollar Turkish Liras
}

\author{
Merve KILINÇ \\ Cantürk KAYAHAN ${ }^{2}$
}

\begin{abstract}
There are numerous methods used in literature on predictive risks and benefits of investment instruments. Methods of value at risk are within the methods proposed by JP Morgan, as well. Value at risk makes a risk prediction according to three principles basically. Historical simulation method has been employed in this study. Average daily (purchase-sale) parities of the investment instruments between the years of 2008-2016 have been utilized in the survey. In order to predict the risk status of the basic investment instruments used and accepted by all in Turkey. According to the findings, dollar has been determined to be the securities having the highest one-day risk. The high risk of the dollar drags investors to a large extent in profit or loss. Specifiying the factors affecting the volatility of the dollar in order for investors to follow the course of the dollar carefully and reach the maximum earnings will have a great benefit in rational decisions. Afterwards Granger causality analysis was, therefore, applied in this study. According to the results of the analysis, credit default swaps were placed on the top among the factors that could be accepted as a reason for dollar volatility.
\end{abstract}

Key words: Historical Simulation Method, Risk, Granger Causality Analysis

Jel Codes: E 47, G 32, J 49

$\ddot{O z e t}$

Yatırım araçlarının öngörüsel riskleri ve kazançları adına literatürde kullanılan çok sayıda yöntem bulunmaktadır. Riske Maruz Değer yöntemleri de JP Morgan tarafindan önerilen yöntemlerin arasında yer almaktadır. Riske Maruz Değer (Value at Risk) temel olarak üç prensibe göre risk tahmini yapmaktadır. Bu çalışmada ise tarihsel verilerin kullanıldığı Tarihsel Simülasyon yöntemi kullanılmıştır. Türkiye'de her kesim tarafından kabul gören ve kullanılan temel yatırım araçlarının riskliliklerini tahmin etmek için yatırım araçlarının 2008-2016 yılları arasındaki günlük ortalama (alıș-satıș) paritelerinden yararlanılmıştır. Elde edilen bulgulara göre dolar en yüksek 1 günlük riske sahip varlık olarak tespit edilmiştir. Doların riskinin yüksek olması yatırımcıları büyük oranda kâr ya da zarar aralığına sürüklemektedir. Yatırımcıların doların seyrini dikkatli bir şekilde takip edebilmesi ve maksimum kazanca ulaşabilmesi için doların volatilitesini etkileyen faktörleri de bilmesi rasyonel karar vermelerinde büyük oranda fayda sağlayacaktır. Bu sebeple çalışmanın devamında Granger Nedensellik analizi yapılmıştır. Analiz sonuçlarına göre dolar volatilitesinin nedeni olarak kabul edilebilecek faktörler arasında kredi temerrüt swapları ilk sirada yer almıştır.

Anahtar Kelimeler: Tarihsel Simülasyon Yöntemi, Risk, Granger Nedensellik Analizi

Jel Kodu: E 47, G 32, J 49

\footnotetext{
${ }^{1}$ Araş.Gör. Burdur Mehmet Akif Ersoy Üniversitesi, mervekilinc@mehmetakif.edu.tr

2 Prof.Dr. Afyon Kocatepe Üniversitesi, ckayahan@aku.edu.tr
} 


\section{Introduction}

As the life standards change and gets faster, activities of people and systems change dramatically as well. Especially the acceleration of information flow affected finance and money market directly. Although the flow of information provides an advantage in many respects in general, it may sometimes be a disadvantage. The volatilities appearing in investment instruments can be seen as an example for these disadvantages. The investment tools being affected by many factors can be re-evaluated depending on the speed of information flow and according to the conditions of the changing factors. Rapidly changing security structures can result in unpredictable losses or gains that are far above their estimates for the investors. Provided this situation is not foreseen for institutional and individual investors, it could create bigger risks.

In this study, maximum risks that Dollar, Euro and Gold which are among the popular and basic investment instruments may constitute for their investors have been tried to be estimated. Different risk calculation methods are examined under 2 titles. There are many risk estimation methods proposed in the financial world. These methods work with different assumptions, data groups and algorithms. Although there are various methods for measuring the risks of the investment instruments determined, JP Morgan's Value-at-Risk approach is considered and historical simulation method which is one of the methods proposed by this approach has been used.

As it is a relatively easier to comprehend, Historical Simulation Method explained in depth in the methodology section is an typically preferred method due to ease of handling. The results obtained from the historical simulation method which works on the assumption of "History repeats itself" are in the final section of this study. According to the findings Dollar has high level of risk. The main reason of this risk is the volatilities occuring in Dollar/Turkish Liras parities. In addition to the Historical Simulation Method, Granger Causality test was applied to the monthly data of the factors frequently used in the literature in order to establish a causal relationship between the variability in parity and the factors that may be the cause of these volatility. Granger Casuality results are discussed in the Results section.

In the next section of the study, investment concept, investment types and investment instruments will be explained.

\section{Investment: Its Concept, Types And Instruments}

Investments occur through financial markets today. Financial markets can vary in terms of its retention time, limits and functions. Fundamentally, financial markets are divided into money markets and capital markets according to maturity of funds. Markets where short term fund supply and demand come together are called "Money markets" while markets where medium and long-term fund supply and demand come together are called bir "Capital Markets" (Ergül,2004:7-8). Apart from this distinction, financial markets are subjected to different classifications like primary and secondary markets according to the transaction of the financial securities, organized and over counter markets according to the organizational form and national and international markets according to the location of transaction.

While capital market instruments are certificates of shares, private sector bonds, state bonds, certificates of gain and loss partnership, participation divident certificate, profit sharing certificate, eurobond, real estate certificate, mutual fund participation shares and asset-backed securities, money markets instruments are treasury bonds, commercial bonds, bank bills, bank guaranteed bills and repo/reverse repo (SPL, 2014:4-5).

Nowadays, investment instruments are just like the ones above in the most basic form while new investment instruments are added every day. They can be listed as Carry Trade, Bitcoin and Hedge Funds etc. But when the micro unit of the society is considered, individuals invest on housing, foreign exchange transactions(dollar, euro, sterling etc.), gold transactions and interest yield. Gold and Exchange transactions have great importance for the investors in Turkey. The most important reason for this is undoubtedly the change from the fixed exchange rate to the fluctuating exchange rate and rates' being variable over Turkısh Liras

Investors follow the fluctuations and they buy foreign currency and gold when exchange rate decreases and aim to sell and make profit. However, sometimes predicting the variability of exchange rates is becoming difficult for the investors, companies or corporations. That's why investors prefer more than one investment instruments in order to eleminate their investment risk or benefit from the returns of different investment instruments (Öncü et. Al., 2015:44). Then a new problem shows up. This problem appears when no answer can be found to the questions of how the profit/loss of the portfolio will occur, what the maximum loss (risk) will be and how to proceed in finding answers to these questions. 


\section{Risk: Its Concept, Types and Historical Development of Risk Evaluation Methods}

F. H. Knight seperated the risk from the uncertainity in his work named Risk, Uncertainity and Profit in 1921. According to Knight, the risk is, to some extent, controllable by the help of an insurance system based on the classification of different initiatives according to their risks. Uncertainity can not be the subject of any calculations. In particular, Knight argues that the theory of probability can not help predicting the economic consequences of decisions made in the context of uncertainty (Buğra, 2003:253).

According to Shubik (1983) and Friedmann and Kim (1988), while the risk is an evaluation of the importance of uncertainty against a certain security, uncertainty is an environmental characteristic (Demirag and Goddard, 1995: 269). According to Kayahan and Topal (2009) it means testing the uncertainity within certain limits or determining it numerically.

Based on the definitions above, the amount that an investor (individual, institution or enterprise) can renounce within a certain period of time is explained as risk. The biggest problem for the investors in small or large-scale investments arises within the framework of this fact. It is classified under various headings according to the content seen in the variability occuring in environmental, political and financial etc. conditions. These risks are shown in the schema below.

Schema 1: Risk Types

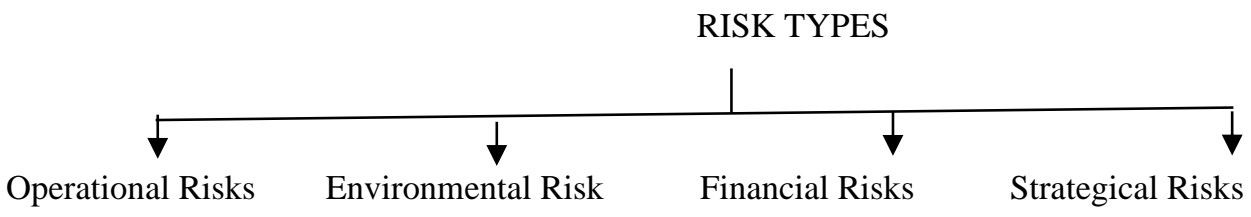

If the risk types are defined briefly: Financial risks represent the risks that arise as a result of the financial position and preferences of the institution and the risks arising from credit, interest rate, cash, financial markets and commodity prices are the first to come to mind. Operational risks refer to risks that may prevent an organization from performing its basic business activities. Risk headings such as procurement, sales, product development, information management, law and brand management are some of the risks in this category. Strategic risks are structural risks that may prevent an organization from reaching its targets in the short, medium or long terms. Risks such as planning, business model, business portfolio, corporate governance and market analysis are typical examples of strategic risks. Environmental risks are risks that arise independently from the activities of the organization but which may affect the company depending on the preferences of the institution. Catastrophic (like natural disasters) risks, legal regulations, customer trends, competitors, changes in the sector, economic and political changes can be an example of the risks in this category (Solar, 2009: 9).

In this study, it is possible to collect the financial risk that will be considered empirically under four headings which are market risk, liquidity risk, credit risk and operational risks. One of them is market and it is the financial loss probability deriving from the unexpected changes in exchange rate, interest rate, stock and goods quotation (Yücel et.al., 2007:107; Bolak, 2004:9). The globalization of the markets, the expansion of the companies and the increase in the competition caused the market risk to be prominent among the mentioned risks above and the most important financial risks that the enterprises were exposed to in the open economies became the risks arising from the exchange rate and interest rate changes (Yücel et. Al., 2007:107).

The currency risk, which will be specifically discussed in this study, can be defined as the change arising from the appreciation or depreciation of the domestic currency against foreign currencies. The need for the management of the exchange rate risk arose after the collapse of the Bretton Woods system in 1973, when countries had different currencies, foreign currencies had different values between each other and the companies made their transactions in different currencies and the exchange rate risk arose (Doğanay, 2016:151). The currency risk cannot be completely eliminated, but there is always a solution. Foreign exchange risk is of critical importance especially for companies operating in the international market. Empirical studies show that the profits of international companies are affected by the fluctuations in exchange rate market (Kayahan and Topal, 2009: 183; Popov and Stutzmann, 2003: 4). Especially international companies are directly affected by exchange rate changes because most of their production resources are based on foreign countries. Therefore, these companies are exposed to exchange costs (wages, taxes, material, etc.) and need to manage them. Other small companies are affected by the interest and exchange rates indirectly. In addition, the impact of exchange rate changes on revenues and expenditures in foreign exchange due to foreign exchange contracts, which have not yet been obtained, also 
determines the future profitability of companies. When the foreign currency denominated securities and liabilities are converted into national currency, uncertainties in exchange rates and uncertainties that may arise in exchange rates when liabilities are paid out, stand out as impressive factors in the cost structure and competitiveness of companies (Kayahan and Topal, 2009: 183; Bolgün, 2002: 47). But the exchange rate risk is is among the variables that want to be considered not only by individuals but also by the investors while creating a portfolio . Especially in recent years, due to the rapid changes in the Middle East conflicts and economic conjunctures, the conditions of international markets have become more suitable for volatility Therefore, every investor who does not want to lose is now willing to measure, evaluate and take precaution against possible losses.

Financial risk management is a continuous function with mathematical expression as a concept that includes risk control. In other words, financial risk management includes a dynamic process in which the decisions taken are continuously reviewed and new measures are taken if necessary as a result of many financial indicators associated with investors' special circumstances. In financial risk management, the necessity to review existing rights and obligations in the daily, short-term and long-term perspectives reveals the importance of the concept of time (Çelik ve Kaya, 2019:765-788; Çelik, 2019: 63-74; Çelik, 2019: 151-160). The success of financial decisions is not only about accurate decisions taken at the right time but also their timely implementation. Timing is one of the most important aspects of financial management (Sayllgan, 1995:324-325).

Although the methods such as Stress Tests, RiskMetrics and CreditMetrics with the models proposed by Markowitz and Sharp are used and recommended by BIS (Bank for International Settlement) and similar financial authority institutions in financial risk management, historical simulation method which is among Value At Risk (VAR) models by JP Morgan will be used.

\section{Methodology}

\subsection{Value At Risk}

Value at Risk ( $\mathrm{VaR}$ ) is a measure of the maximum potential change in a portfolio value of a financial securities at a given time interval. The onset of VAR, J.P. It is a popular market risk measurement method based on Morgan (1980). VAR gives the answer to the question of how much we may lose a certain time period (Çelik, 2010: 21).

It can be seen that VAR techniques emerged and developed after financial scandals in the early 1990s. In Turkey, the use of $\mathrm{VaR}$ in market risk measurement was made compulsory for risk management and internal control systems with the new Banking Law enacted in 1999. In the determination of risk measurement methods, the return of the portfolio is one of the important factors with the return of the financial securities that make up the portfolio and the linear dependence. The biggest advantage of VAR is express different positions in a single monetary value by taking into account the correlation of risk factors (Çatal and Albayrak, 2013: 5190).

Volatility is the measurement of price movements. The greater volatility of securities in the portfolio is the greater the risk of loss of that size might be. The VaR method uses the volatility of securities in the portfolio to estimate the maximum risk of an investor (Butler, 1999: 6). The VaR method is not just a risk management tool. Apart from this, it is also used in the reporting of information about the risks of the companies, to determine the use of resources within the company (resource allocation) and to measure performance as it allows the returns to be adapted to risk (Gürsakal, 2007: 2). In addition, the VaR method estimates the total impact of market risks such as interest rate, inflation, exchange rate and share prices. Thus, the VaR method represents the expected total loss for a predetermined period and a certain security and liability that is sensitive to changes in market factors for the confidence interval. It can be used for a single investment on a micro basis as well as at a macro level, such as portfolio investments (Demireli and Taner, 2009: 130; Aktaş, 2008: 246).

There are some parameters that the analyst should determine before proceeding to the calculation of the VAR. These parameters are: time interval, confidence level, portfolio value and standard deviation.

Investment time interval varies from investment to investment. It can be for one day, one month, yearly or longer. The time interval of the investment is generally related to the ease of liquidity of the investment. Although daily or monthly periods are employed, the period depends on the investment. The adjusted time is used in the calculation of $\mathrm{VaR}$. The term $\sqrt{ } T$ refers to the corrected time interval. The $\mathrm{T}$ concept is expressed as the yield range in the calculation of the standard deviation. If the standard deviation is calculated with the help of daily returns and the holding period is one day, T value is equal to 1 (Irs, 2017: 30; Karan, 2013: 754-757). 
The confidence level in the VaR calculations is the parameter that gives the reliability of the calculations. The Basel Committee requires a $99 \%$ confidence level and a one-sided confidence interval. The higher the confidence interval is, the higher the resulting VAR figure will be (Kayahan and Topal, 2009: 188; Akçay and Bolgün, 2005: 393).

The portfolio value represents the total amount invested for the security or portfolio. The standard deviation is calculated according to the price fluctuations of the securities. The standard deviation is calculated by the percentage of price change of the security. For daily standard deviation calculation, a minimum of 250 data is used and this constitutes the sampling period (Irs, 2017: 30).

VAR covers three approaches which are Parametric, Historical Simulation and Monte Carlo Simulation. Parametric approximation is a method based on correlation and covariance matrices and includes the assumption of normal distribution. The historical simulation approach is a method that shows the current loss in a certain level of confidence in the even that has occurred in the past and causes loss. Monte Carlo simulation approach is a method that calculates the risk value based on the production of random numbers that will converge to the normal distribution (Ural and Adakale, 2009: 24-25).

The weakest aspect of the VaR calculation methods is that it does not show the "worst case". As known, the probability distributions represent the range within the specified confidence interval. However, though the probability in real life is very low, there are some events outside this area. Although the probability is very low, it cannot be said that such an event will never happen. Another important issue is that VaR models do not show a total loss. VaR, for example, shows that a million dollars are at risk on a trading day, and cannot provide information about losses in the second, third and subsequent days (Demireli and Taner, 2009: 131). Fat tail distribution may be a major risk factor for investors. Fat tail simply means sudden and large amount of increases/ decreases at value of the securities. The fact that the fluctuations in large quantities cannot be predicted by the VaR method is among the disadvantages that make the method inadequate.

\subsubsection{Historical Simulation Method}

This method is based on historical events. If there is a major market movement during the period in which the data is handled, this will be included in the data group to be analyzed. This is an advantage. Because the addition of low-probability events to the data set facilitates the estimation of unexpected results (Butler, 1999: 50-51).

Historical VaR can be employed even if it does not serve the conditions needed by parametric tests as it is not testing based on the distributions of the data. In this method, scenarios are produced from historical data, future profit and loss distributions of the portfolio are determined and VaR is reached at the selected confidence level by using historical changes of risk factors of securities in the portfolio, (Eser, 2010: 28).

The RMD formula calculated according to the historical simulation method is calculated as follows (Y1ldirım and Çolakyan, 2014: 10):

$$
\mathbf{R}_{\mathrm{p}, \mathrm{t}}=\sum_{\mathrm{i}=1}^{\mathrm{n}} \mathrm{x}_{\mathrm{i}} \cdot \mathbf{r}_{\mathrm{i}, \mathrm{t}} \quad \mathrm{t}=0,1, \ldots, \mathrm{T}
$$

$\mathrm{Rp}, \mathrm{t}: \mathrm{t}$ return of portfolio over the period

$\mathrm{Xi}$ : i. weight of an security in a portfolio

$\mathrm{R}, \mathrm{t}$ : i. t. return on observation

$\mathrm{N}$ : refers to the number of security in the portfolio.

According to the historical RMD method; within the value distribution obtained for the portfolio, a value is selected according to the confidence interval determined. The current value of the portfolio is multiplied by the weighted return changes found in the historical process which includes the past 252 business days. The profit (P) - loss (L) distributions of the portfolio at the end of each day are calculated and sorted from small to large (Kayahan and Topal, 2009: 191; Tas and Tiftikçi, 2005: 12). Therefore the biggest loss amount is determined by date (Kayahan and Topal, 2009: 191).

If the steps are rendered schematically: 
Schema 2: Calculation Stages of Historical VAR

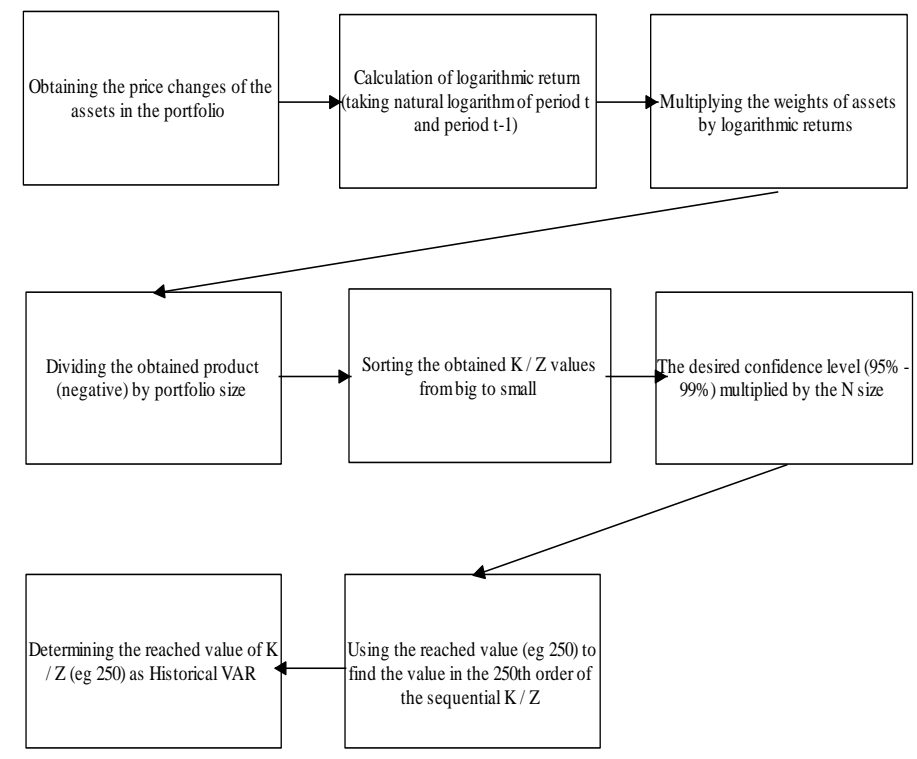

The advantages and disadvantages of the historical VaR are as follows:

Advantages:

- No assumptions are made regarding the distribution of risk factors of securities in the portfolio,

- It is not necessary to calculate variability and correlation as the analysis is done via historical data.

- Excessive values are used as long as the data obtained are included.

- Integrity between markets is accepted.

Disadvantages:

- It is a method built on the data in the sampling period,

- It can ignore the structural changes that will occur in the market soon,

- Sensitivity analysis does not always work,

- If the securities in the portfolio are too complex or contain too many securities, they may not work well in measurement,

- It may not work well if the weights of the securities in the portfolio change (Irs, 2017: 37; Karan, 2013: 756-757).

Effective and weak aspects of VaR methods are as follows:

Table 1: Advantages and Disadvantages of VaR Methods

\begin{tabular}{|c|c|c|c|}
\hline & Parametric VaR & Historical VaR & Monte Carlo Simulation \\
\hline $\begin{array}{c}\text { Simplicity of } \\
\text { calculation }\end{array}$ & High & High & Low \\
\hline $\begin{array}{c}\text { Simplicity of } \\
\text { practice }\end{array}$ & High & High & Low \\
\hline $\begin{array}{c}\text { Reportability } \\
\text { To the upper level }\end{array}$ & Low & High & High \\
\hline $\begin{array}{l}\text { Buying in } \\
\text { Derivatives }\end{array}$ & Low & High & \\
\hline
\end{tabular}




\begin{tabular}{|c|c|c|c|}
\hline $\begin{array}{c}\text { Considering } \\
\text { Unexpected Events }\end{array}$ & Low & Low & High \\
\hline Limitations & $\begin{array}{l}\text { Completely based on } \\
\text { normal distribution } \\
\text { assumption, not suitable } \\
\text { for handling derivative } \\
\text { products, not } \\
\text { comprising unusual } \\
\text { market movements }\end{array}$ & $\begin{array}{c}\text { Having difficulty in } \\
\text { obtaining historical data, } \\
\text { Unusual movements can } \\
\text { not be covered if unusual } \\
\text { price movements are not } \\
\text { included in the data set } \\
\text { used }\end{array}$ & $\begin{array}{l}\text { High risk of modeling } \\
\text { Inclusion of complex } \\
\text { calculations and difficult } \\
\text { intelligibility }\end{array}$ \\
\hline Advantages & $\begin{array}{l}\text { High success in } \\
\text { portfolios with linear } \\
\text { returns }\end{array}$ & $\begin{array}{c}\text { Conceptually simple and } \\
\text { clear } \\
\text { Be applicable to any } \\
\text { position }\end{array}$ & $\begin{array}{c}\text { Success in handling } \\
\text { complex positions } \\
\text { Success in handling non- } \\
\text { linear positions }\end{array}$ \\
\hline
\end{tabular}

Source: Irem Cemre IRS. Measurement of Market Risk in Foreign Exchange Markets: A practise with Value at Risk Method, Dokuz Eylül University Institute of Social Sciences, 2017, İzmir, p. 38; Candan, H. and Özün, A. (2014). Risk Management in Banks and Basel II. Istanbul: Turkey Isbank Cultural Publications, p.101.

\section{An Overview into Literature}

The table below contains some of previous studies about foreign exchange risk

Table 2: Selected Studies About Foreign Exchange Risk

\begin{tabular}{|c|c|c|c|}
\hline WRITER/HISTORY & DATA RANGE & METHOD & FINDINGS \\
\hline $\begin{array}{l}\text { Jacque Laurent L. } \\
\text { (1983) }\end{array}$ & Definitional & Definitional & $\begin{array}{l}\text { Findings of existing currency risk } \\
\text { management models and gaps of } \\
\text { variables used in these models. }\end{array}$ \\
\hline Duman M. (2000) & 1998-1999 & Value At Risk & $\begin{array}{c}\text { It is concluded that the only method } \\
\text { should not be VaR which is needed to } \\
\text { be used to determine risk fact in banks } \\
\text { emprically. }\end{array}$ \\
\hline $\begin{array}{c}\text { Kanas A. and } \\
\text { Kouretas G.P. (2001) }\end{array}$ & $1975-1993$ & GARCH $(1,1)$ & $\begin{array}{c}\text { It is concluded that } \mathrm{GARCH}(1,1) \\
\text { model can measure exchange rate } \\
\text { volatility. }\end{array}$ \\
\hline $\begin{array}{c}\text { Acaravc1 and Öztürk } \\
(2003)\end{array}$ & 1989-2002 & Cointegration Model & $\begin{array}{l}\text { The volatility and uncertainty in } \\
\text { exchange rates are effective in } \\
\text { decreasing the export demand. }\end{array}$ \\
\hline Akan et al. (2003) & $1990-2002$ & $\begin{array}{c}\text { Parametric VAR and } \\
\text { EWMA }\end{array}$ & $\begin{array}{c}\text { In order to calculate the objective } \\
\text { value of the risk, the lambda values } \\
\text { used in the EWMA method have a } \\
\text { critical value. }\end{array}$ \\
\hline
\end{tabular}




\begin{tabular}{|c|c|c|c|}
\hline $\begin{array}{c}\text { Çiçek and Öztürk } \\
\text { (2007) }\end{array}$ & 2001-2006 & GARCH Model & $\begin{array}{c}\text { The existence of a significant and } \\
\text { negative relationship between } \\
\text { uncertainty in stock investments and } \\
\text { exchange rates. }\end{array}$ \\
\hline $\begin{array}{c}\text { Kayahan and Topal } \\
\text { (2009) }\end{array}$ & Intermittent & $\begin{array}{c}\text { Historical VaR and } \\
\text { Backward Test }\end{array}$ & $\begin{array}{c}\text { Finding that the risk scores obtained } \\
\text { with historical RMD results are in } \\
\text { compliance with reality. }\end{array}$ \\
\hline $\begin{array}{c}\text { Belk P.A. and Glaum } \\
\text { M. (2012) }\end{array}$ & Questionnaire & $\begin{array}{c}\text { The result that the companies in } \\
\text { England consider Exchange rate risk } \\
\text { as a central element and they describe } \\
\text { themselves in a group avoiding from } \\
\text { risk totally despite using different } \\
\text { methods }\end{array}$ \\
\hline
\end{tabular}

The fact that exchange rate risk is a matter that is considered by individual investors, institutions and multinational companies has also been mentioned in the previous sections of the study. The exchange rate's interactions with other economic activities and the measurement of the risk that might occur in the exchange rate are still considered to be the pending aspects of the literature studies. The relationship between the exchange rate and the trade volume was evaluated by Black (1973), the share of the stock investments by Çiçek and Öztürk (2007) and the exchange rate risk and the export demand relationship by Acaravcı and Öztürk (2003) using different methods. As a result of the findings, there was a negative relationship between foreign exchange volatility and export demand and stock investments, it was found out that trade volume would increase when corrected exchange rate systems were used. When the statistical and econometric models used for measurement of exchange rate risk. Kanas and Kouretas (2001) concluded that GARCH $(1,1)$ method gives results parallel to the reality and Kayahan and Topal (2009) detected that Historical Simulation method gives results parallel to the reality. In response to these studies, Duman (2000) argued that the use of VAR models alone was insufficient in measuring the risk phenomena in banks, while the reason for this idea was to use parametric or hypothetical methods. Akan et al. (2003) stated that the lambda parameter in the EWMA model is critical and may cause misleading answers; Jacque (1983) concluded that existing risk measurement and management models are insufficient.

In the literature, there are also studies on how multinational companies meet, calculate and manage the currency risk. While Belk and Glaum (2012) conducted this survey for companies in the UK, other studies conducted in this parallel approach handled regionally different companies.

It can be understood from the literature that the effects of the currency risk, the techniques used in measuring, measuring and how the companies have adopted a management style against these are still the topics that continue to be investigated.

\section{Implimentation and Findings}

In this study, USD / TL, EURO / TL, ONS / TL and EURO / USD daily parities between 01.01.2007 and 31.12.2016 are studied and Historical Simulation Method is used in RMD calculations. Aforesaid parities for 1 year which has 252 days of data have been obtained from the Central Bank of the Republic of Turkey database. The purpose of the study is to estimate the amount of risk that the investor might encounter in different portfolio sizes and different security weights.

Portfolios used in the study and The weights used in the portfolios are as follows:

Table 3: Varieties and Form of the Portfolio used in the study

\begin{tabular}{|c|c|c|c|c|}
\hline & \multicolumn{4}{|c|}{$1.000 .000 \mathrm{TL}$} \\
\hline SECURITY & USD & EURO & ONS & $\begin{array}{c}\text { EURO(ON DOLLAR } \\
\text { BASED) }\end{array}$ \\
\hline WEIGHT & $\% 25$ & $\% 25$ & $\% 25$ & $\% 25$ \\
\hline
\end{tabular}




\begin{tabular}{|c|c|c|c|c|}
\hline PORTFOLIO & \multicolumn{4}{|c|}{$1.000 .000 \mathrm{TL}$} \\
\hline SECURITY & \multicolumn{4}{|c|}{ USD } \\
\hline WEIGHT & \multicolumn{4}{|c|}{$\% 100$} \\
\hline PORTFOLIO & \multicolumn{4}{|c|}{$1.000 .000 \mathrm{TL}$} \\
\hline SECURITY & \multicolumn{4}{|c|}{ EURO } \\
\hline WEIGHT & \multicolumn{4}{|c|}{$\% 100$} \\
\hline PORTFOLIO & \multicolumn{4}{|c|}{$1.000 .000 \mathrm{TL}$} \\
\hline SECURITY & \multicolumn{4}{|c|}{ GOLD } \\
\hline WEIGHT & \multicolumn{4}{|c|}{$\% 100$} \\
\hline PORTFOLIO & \multicolumn{4}{|c|}{$500.000 \mathrm{TL}$} \\
\hline SECURITIES & USD & EURO & ONS & $\begin{array}{c}\text { EURO(ON DOLLAR } \\
\text { BASES) }\end{array}$ \\
\hline WEIGHT & $\% 25$ & $\% 25$ & $\% 25$ & $\% 25$ \\
\hline PORTFOLIO & \multicolumn{4}{|c|}{$500.000 \mathrm{TL}$} \\
\hline SECURITY & \multicolumn{4}{|c|}{ USD } \\
\hline WEIGHT & \multicolumn{4}{|c|}{$\% 100$} \\
\hline PORTFOLIO & \multicolumn{4}{|c|}{$500.000 \mathrm{TL}$} \\
\hline SECURITY & \multicolumn{4}{|c|}{ EURO } \\
\hline WEIGHT & \multicolumn{4}{|c|}{$\% 100$} \\
\hline PORTFOLIO & \multicolumn{4}{|c|}{$500.000 \mathrm{TL}$} \\
\hline SECURITY & \multicolumn{4}{|c|}{ GOLD } \\
\hline WEIGHT & \multicolumn{4}{|c|}{$\% 100$} \\
\hline PORTFOLIO & \multicolumn{4}{|c|}{$50.000 \mathrm{TL}$} \\
\hline SECURITIES & USD & EURO & ONS & $\begin{array}{c}\text { EURO(ON DOLLAR } \\
\text { BASES) }\end{array}$ \\
\hline WEIGHT & $25 \%$ & $25 \%$ & $\% 25$ & $\% 25$ \\
\hline PORTFOLIO & \multicolumn{4}{|c|}{$50.000 \mathrm{TL}$} \\
\hline SECURITY & \multirow{2}{*}{\multicolumn{4}{|c|}{ USD }} \\
\hline WEIGHT & \multicolumn{3}{|c|}{$\begin{array}{c}\% 100 \\
50000 \mathrm{TL}\end{array}$} & \\
\hline PORTFOLIO & \multirow{2}{*}{\multicolumn{4}{|c|}{$\begin{array}{c}50.000 \mathrm{TL} \\
\text { EURO }\end{array}$}} \\
\hline SECURITY & \multicolumn{3}{|c|}{ EURO } & \\
\hline WEIGHT & \multicolumn{4}{|c|}{$\% 100$} \\
\hline PORTFOLIO & \multicolumn{4}{|c|}{$50.000 \mathrm{TL}$} \\
\hline SECURITY & \multicolumn{4}{|c|}{ GOLD } \\
\hline WEIGHT & \multicolumn{4}{|c|}{$100 \%$} \\
\hline
\end{tabular}

As a result of the analysis, since the probable profit / loss amount of each security is required to be evaluated separately, the securities are assumed to be equal weight and calculated and then they are assumed to be the single security (\%100 weight) and calculated.

As previously mentioned in the methodology part, logoritmic returns were calculated in the first stage, in the second phase logarithmic returns and the weights of the securities within the portfolio were multiplied, In the third stage, the logarithmic yield * weight values obtained for each day were collected and profit / loss values were obtained and in the fourth stage, the profit / loss values are listed from the larger one to smaller one. At the last stage, VaR values should be estimated for different confidence intervals. At this step, the data size $(\mathrm{N}) *$ confidence rating $(0.95$ and 0.96$)$ was multiplied. As a result of the procedure, $\mathrm{VAR}=2433,9$ was found at 0,95 confidence level and $\mathrm{VaR}=2536,38$ at 0,99 confidence level. The fact that the VaR values address different levels of confidence is directly related to the type of data used and the principles of the method used. Historical VAR uses data that existed in the past with the assumption that history repeats itself. Data do not always act in a standard direction. Exchange rates show fluctuations in the upper and lower directions over time. Some of these fluctuations occur at normal and acceptable or predictable levels while others occur at extreme levels. It is previously stated that such situations are called fat tail. While another expression of 95\% confidence level is 5\% deviation from the required value, another expression of $99 \%$ confidence level is $1 \%$ deviation from the required level. In other words, while a calculation of $95 \%$ confidence level is made, $5 \%$ of the data is not included in the calculation results, while the portion not included in the $99 \%$ confidence level is $1 \%$. For this reason, the historical VaR values (profit / loss) calculated with different levels of confidence include distance because they add different values to their calculations. In this case, the researcher / investor will also want to know the maximum profit / loss in the most unusual or unpredictable scenarios. Thus, the historical VaR values calculated with a $99 \%$ confidence level will undoubtedly be greater than $95 \%$ confidence level. Thus, the historical VaR values calculated with a $99 \%$ 
confidence level will undoubtedly be greater than $95 \%$ confidence level. This will be a numerical description of the worst / best scenario for the researcher / investor.

It was used (1-confidence level) * $\mathrm{N}$ formula in order to calculate maximum gain of the portfolio. The value of the resulting $\mathrm{VaR}$ in the sequential $\mathrm{P} / \mathrm{L}$ will give the investor's maximum profit for the portfolio. In this study, $\mathrm{VaR}=$ 25 is the confidence level of 0.99 calculated for maximum profit.

For different confidence levels, the investor's 1-day profit / loss amount is as follows for different portfolios types and structures.

Table 4: 1-day Profit / Loss Amounts Calculated for Different Portfolios (0,99 Confidence Level)

\begin{tabular}{|c|c|c|c|c|c|}
\hline PORTFOLIO & $\begin{array}{l}\text { 1.000.000 TL } \\
\text { (EQUAL } \\
\text { WEIGHT) } \\
\end{array}$ & PORTFOLIO & $\begin{array}{c}\text { 500.000 TL } \\
\text { (EQUAL } \\
\text { WEIGHT) } \\
\end{array}$ & PORTFOLIO & $\begin{array}{c}\text { 50.000 TL } \\
\text { (EQUAL } \\
\text { WEIGHT) }\end{array}$ \\
\hline LOSS & $\begin{array}{c}- \\
\text { 13.923.963.465,27 } \\
\text { TL }\end{array}$ & LOSS & $\begin{array}{c}- \\
6.961 .981 .732,63 \\
\text { TL }\end{array}$ & LOSS & $-668,55 \mathrm{TL}$ \\
\hline PROFIT & $\begin{array}{c}9.896 .807 .788,23 \\
\text { TL } \\
\end{array}$ & PROFIT & $\begin{array}{c}4.948 .403 .894,11 \\
\text { TL }\end{array}$ & PROFIT & $377,28 \mathrm{TL}$ \\
\hline PORTFOLIO & $\begin{array}{c}\text { 1.000.000 TL } \\
\text { (DOLIAR) }\end{array}$ & PORTFOLIO & $\begin{array}{c}\text { 500.000 TL } \\
\text { (DOLIAR) }\end{array}$ & PORTFOLIO & $\begin{array}{l}50.000 \mathrm{TL} \\
(\text { DOLlAR) }\end{array}$ \\
\hline LOSS & $\begin{array}{c}-6.384 .656 .236,95 \\
\text { TL }\end{array}$ & LOSS & $\begin{array}{c}- \\
\text { 3.192.328.118,47 } \\
\text { TL }\end{array}$ & LOSS & $-319,232 \mathrm{TL}$ \\
\hline PROFIT & $\begin{array}{c}6.425 .944 .431,47 \\
\text { TL }\end{array}$ & PROFIT & $\begin{array}{c}3.212 .972 .215,74 \\
\text { TL }\end{array}$ & PROFIT & $321,297 \mathrm{TL}$ \\
\hline PORTFOLIO & $\begin{array}{c}\begin{array}{c}1.000 .000 \\
\text { (EURO) }\end{array} \\
\end{array}$ & PORTFOLIO & $\begin{array}{c}\mathbf{5 0 0 . 0 0 0} \text { TL } \\
(\text { EURO) }\end{array}$ & PORTFOLIO & $\begin{array}{c}50.000 \text { TL } \\
(\text { EURO) }\end{array}$ \\
\hline LOSS & $\begin{array}{c}-6.183 .099 .986,52 \\
\text { TL }\end{array}$ & LOSS & $\begin{array}{c}- \\
3.091 .549 .993,26 \\
\mathrm{TL}\end{array}$ & LOSS & $-309,154 \mathrm{TL}$ \\
\hline PROFIT & $\begin{array}{c}5.361 .090 .893,55 \\
\text { TL }\end{array}$ & PROFIT & $\begin{array}{c}2.680 .545 .445,77 \\
\text { TL }\end{array}$ & PROFIT & $268,054 \mathrm{TL}$ \\
\hline PORTFOLIO & $\begin{array}{c}1.000 .000 \mathrm{TL} \\
(\text { GOLD })\end{array}$ & PORTFOLIO & $\begin{array}{c}\text { 500.000 TL } \\
\text { (GOLD) }\end{array}$ & PORTFOLIO & $\begin{array}{c}50.000 \mathrm{TL} \\
\text { (GOLD) }\end{array}$ \\
\hline LOSS & $\begin{array}{c}-5.443 .499 .984,69 \\
\text { TL }\end{array}$ & LOSS & $\begin{array}{c}- \\
2.721 .749 .992,34 \\
\text { TL }\end{array}$ & LOSS & $-272,174 \mathrm{TL}$ \\
\hline PROFIT & $\begin{array}{c}5.272 .055 .485,75 \\
\text { TL }\end{array}$ & PROFIT & $\begin{array}{c}1.947 .022 .716,57 \\
\text { TL }\end{array}$ & PROFIT & $194,482 \mathrm{TL}$ \\
\hline
\end{tabular}

According to the results obtained from the table above, it is seen that the maximum possible losses of portfolios created with equal securities with a confidence level of 0.99 are considerably higher than the maximum possible gains. In this case, the portfolios created with equal weights from the USD, EURO, ONS and EURO / USD investment instruments are highly risky as a result of the historical VaR analysis conducted in 2007 and 2016. While the possible profit of the invester is 10 times as much as its capital, the loss is calculated 14 times as much as its capital.

Looking at the maximum possible earnings and profits of portfolios that consist only of gold, it is seen that the maximum possible loss of gold is higher than the maximum possible profit. When we look at the possible loss and gain of the euro, it has been determined that it is a more risky and profitable investment instrument. In contrast to the gold, Euro and equal weight portfolios, the maximum gain and loss of the dollar was higher than the maximum loss, but despite the high profitability compared to all other portfolio types, it was found that it had a high loss, as well.

When the distribution of the gain / loss situation of dollar according to the Historical VaR Method, which is calculated as the most profitable investment tool, is examined: 
Chart 1: Historical Profit / Loss Distribution of the Dollar

US Dollar Profit and Loss

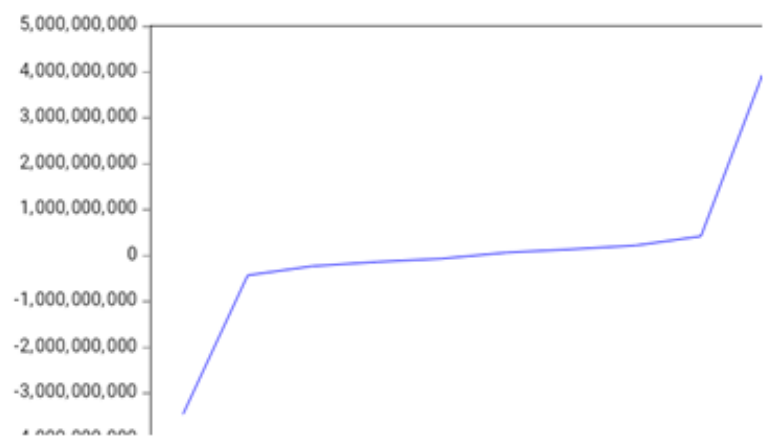

The investments between 2008-2014 tend to move dramatically from non-earnings to profitable situation while the dollar based investments tend to shift from loss to profit between 2007-2008. After 2015, the maximum profit gained by the dollar investment is almost 5 times higher. When USD / TL parity is considered in this term.

Chart 2: Historical Overview of TL / USD:

US Dollar an Turkish Liras

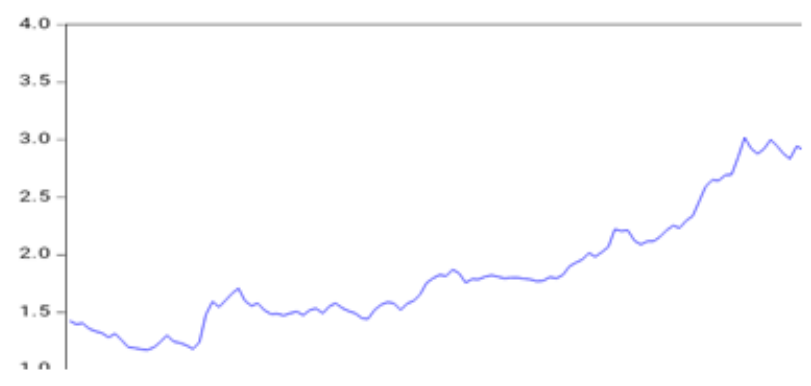

It has been observed that USD / TL parity decreased between 2007-2008, USD / TL parity between 2008-2014 had risen with small jumps and after 2014, the parity increased from TL 2 to TL 3.5.

This sudden leap has many reasons such as inflation, interest, foreign trade balance, oil prices and political risk. In the literature, such interactions can be explained by causality tests in correlation or time series. In the following sections, in order to explain the sudden rise in the dollar, the relationship between the dollar and some possible factors was investigated. These factors are defined as foreign trade balance, inflation and credit default swaps. Among these factors, foreign trade balance and inflation were obtained from the official website of Turkey Statistical Institute (on a montly basis) while credit default swaps were obtained from Bloomberg database (on a montly basis). The results of the causality test reached are as follows:

First of all, the data should be stable at the same level in order to conduct the causality test. For this reason, firstly the stability of the variables was tested. The test was performed by Augmented-Dickey Fuller test. When the differences of the series were taken from the first difference, it was observed that all of them became stationary. Below are the stabilized views of variables at I(1) level. 
Chart 3: Stabilizing Series with Difference

US Dollar

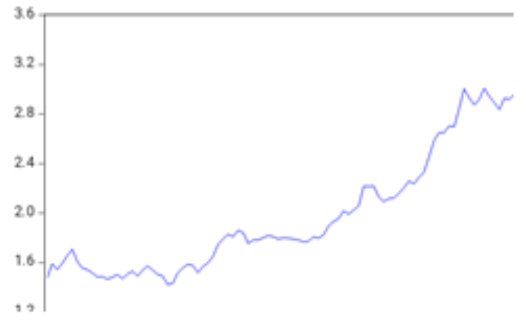

Inflation

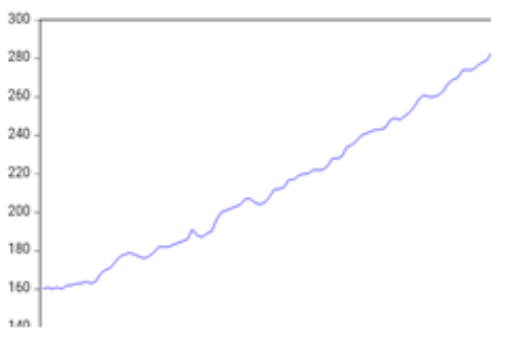

Balance

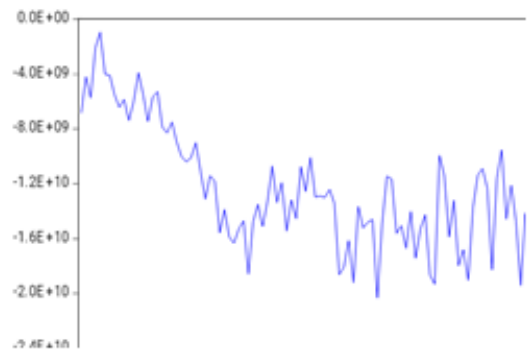

$C D S$

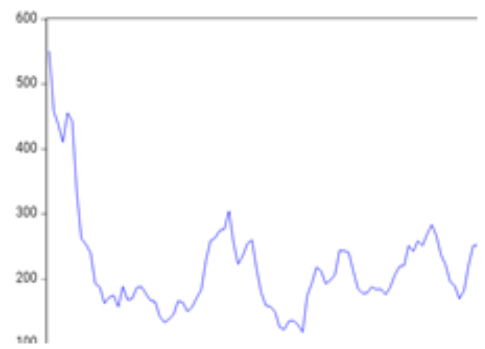

1st. Difference of US Dollar

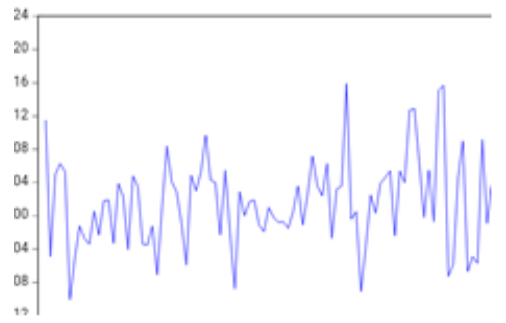

1st. Difference of Inflation

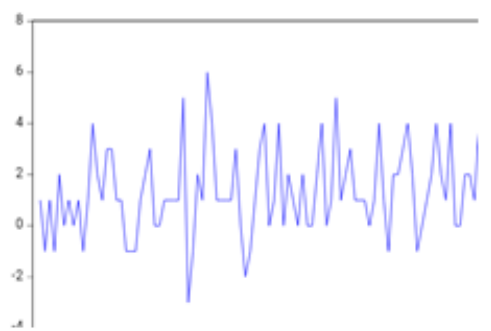

1st. Difference of Balance

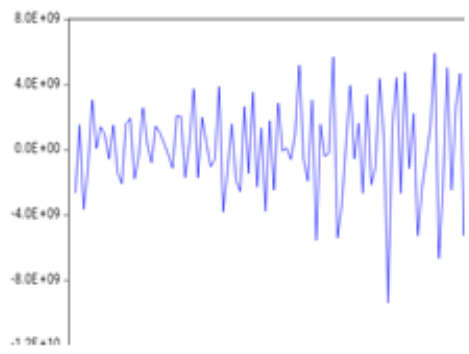

1st Difference of CDS

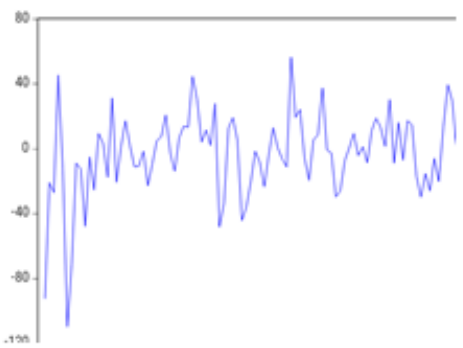

After determining that our variables are stationary in the first differences, it is necessary to determine the appropriate delay length in order to apply the other analyzes. In such cases, the most commonly used method for finding the optimal delay level is the information criteria (Conkar and Vergili, 2017: 63; Brooks, 2008). The lag length was determined by using information criteria. The results are as follows: 
Table 5: The results of delay lagged value

\begin{tabular}{ccccccc}
\hline Lag & LogL & LR & FPE & AIC & SC & HQ \\
\hline & & & & & & \\
& & & & & & \\
1 & -2297.900 & NA & $3.91 \mathrm{e}+18$ & 54.16236 & $54.27730^{*}$ & $54.20859^{*}$ \\
1 & -2274.318 & 44.38942 & $3.28 \mathrm{e}+18$ & 53.98396 & 54.55870 & 54.21514 \\
3 & -2257.673 & 29.76566 & $3.23 \mathrm{e}+18$ & 53.96878 & 55.00331 & 54.38489 \\
4 & -2243.236 & 24.45848 & $3.38 \mathrm{e}+18$ & 54.00555 & 55.49987 & 54.60661 \\
5 & -2222.750 & 32.77722 & $3.08 \mathrm{e}+18$ & 53.90000 & 55.85412 & 54.68600 \\
6 & -2202.083 & 31.12145 & $2.81 \mathrm{e}+18$ & 53.79020 & 56.20411 & 54.76114 \\
7 & -2192.303 & 13.80783 & $3.35 \mathrm{e}+18$ & 53.93654 & 56.81024 & 55.09242 \\
8 & -2172.614 & 25.94265 & $3.21 \mathrm{e}+18$ & 53.84975 & 57.18325 & 55.19057 \\
9 & -2156.872 & 19.26047 & $3.42 \mathrm{e}+18$ & 53.85582 & 57.64912 & 55.38159 \\
10 & -2146.769 & 11.41081 & $4.24 \mathrm{e}+18$ & 53.99457 & 58.24765 & 55.70528 \\
11 & -2121.684 & 25.97099 & $3.79 \mathrm{e}+18$ & 53.78079 & 58.49367 & 55.67644 \\
12 & -2105.292 & 15.42732 & $4.28 \mathrm{e}+18$ & 53.77158 & 58.94425 & 55.85217 \\
& -2043.898 & $52.00427^{*}$ & $1.73 \mathrm{e}+18^{*}$ & $52.70348 *$ & 58.33595 & 54.96902 \\
\hline
\end{tabular}

According to LR Test Statistic, Final Prediction Error and Akakike Information Criterion results, the lag length of the monthly data is determined as " 12 ". After providing the necessary information for Granger Causality Analysis, it was tested whether the variables were related with each other in the long term and whether the dependent variable could be better estimated with the lagged values of the independent variable. Granger casuality results are as below:

Table 5: Granger Causality Test Results

Dependent variable: DIFFERENCEEXCHANGERATEOFDOLLAR

\begin{tabular}{cccc}
\hline Excluded & Chi-sq & df & Prob. \\
\hline DIFFERENCEINFLATION & 15.13424 & 12 & 0.2342 \\
DIFFERENCEBALANCE & 16.71488 & 12 & 0.1606 \\
DIFFERENCE CDS & 32.92445 & 12 & 0.0010 \\
\hline All & 60.06908 & 36 & 0.0072 \\
\hline
\end{tabular}

Dependent variable: DIFFERENCEINFLATION

\begin{tabular}{cccc}
\hline Excluded & Chi-sq & df & Prob. \\
\hline DIFFERENCEUSD & 26.62824 & 12 & 0.0087 \\
DIFFERENCEBALANCE & 26.22307 & 12 & 0.0100 \\
DIFFERENCECDS & 25.02334 & 12 & 0.0147 \\
\hline All & 63.80219 & 36 & 0.0029 \\
\hline
\end{tabular}




\begin{tabular}{cccc}
\hline Excluded & Chi-sq & df & Prob. \\
\hline DIFFERENCEUSD & 28.78917 & 12 & 0.0042 \\
DIFFERENCEINFLATION & 37.12077 & 12 & 0.0002 \\
DIFFERENCECDS & 13.27256 & 12 & 0.3495 \\
\hline All & 102.9782 & 36 & 0.0000 \\
\hline
\end{tabular}

Dependent variable: DIFFERENCECDS

\begin{tabular}{cccc}
\hline Excluded & Chi-sq & df & Prob. \\
\hline DIFFERENCEUSD & 4.963848 & 12 & 0.9592 \\
DIFFERENCEINFLATION & 13.93150 & 12 & 0.3051 \\
DIFFERENCEBALANCE & 12.96477 & 12 & 0.3716 \\
\hline All & 34.08568 & 36 & 0.5599 \\
\hline
\end{tabular}

As a result of the analysis, It has been determined that there is a two-way Granger Casuality $(\mathrm{p}=.010, \mathrm{p}=.0002)$ between inflation and foreign trade balance, one-way from the dollar rate to foreign trade balance $(p=.0042)$, oneway from the dollar rate to the inflation $(\mathrm{p}=.0087)$, one-way from Credit Default Swap to Inflation( $\mathrm{p}=.0147)$,oneway from the Credit Default Swap to the dollar rate $(\mathrm{p}=.0010)$.

The schematic view of causality relations is as follows:

Scheme 3: The View of Causality Relations

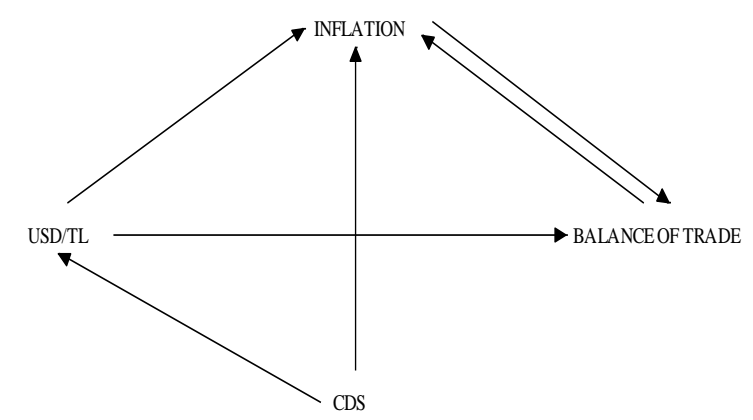

\section{Conclusions and Recommendations}

In this study, investment tools have been examined deeply with their cause/affect relation which handled with two phases. In first stage dollar, euro and gold are discussed as they are the most preferred investment tools by both individual and institutional investors in Turkey. Different portfolio sizes and types, profit / loss and risk were calculated with the historical simulation method. According to the Historical VaR results widely used by the 
investors and researchers in practice and theory: while the daily investments of dollar and euro are highly risky, the profits and losses of investments realized through gold are relatively low compared to other investment instruments. Among the high-risk securities, it was found that the dollar had a higher 1-day maximum gain compared to the Euro. Parallel to the results, when the parity of the securities against TL was examined, it was observed that the dollar rose above 3 TL with high jumps at the end of 2016. It is evident from the results that the predictions of $99 \%$ confidence in historical $\mathrm{VaR}$, which suggests that historical data are the best guide for future conditions, are compatible with real life.

In the second stage, the reasons for the high leap in USD / TL parity were investigated in the economic framework. One of the leading macroeconomic factors in the literature, which have been effective on the dollar: inflation, foreign trade balance and credit default swap were selected as items that could lead to the rise of the Dollar. After determining the macroeconomic factors whose Casuality relationship will be investigated, Granger Casuality Test will be carried out. According to the results of the test, it was found that the only factor that is the reason for the Granger cause is the credit default swap. The credit default swap is briefly described as the amount that the creditor receives as insurance due to the risk of not being able to collect his debt. This price increases when the crisis, political risks etc are expected to happen. It can be understood from these findings and data that financial crisis and political events (coup attemt, increase in terorist incidents, speculations etc.) are the Granger reasons of increases or decreases of dollar rate.

\section{REFERENCES}

ACARAVCI A., ÖZTÜRK İ., (2003) ’Döviz Kurundaki Değişkenliğin Türkiye İhracatı Üzerine Etkisi: Ampirik Bir Çalışma", Review of Social, Economic and Business Studies, 2(4), s.197-206.

AKAN N. B., LANÇER A.O. VE TÜZÜN, Y., (2003) "Parametrik Riske Maruz Değer Yöntemi Türkiye Uygulaması", Bankacılar Dergisi, 45, s.29-39.

AKTAŞ M., (2008) “Türkiye Piyasalarında Parametrik Riske Maruz Değer Modelinin Taşıdı̆̆ı Riskler”, Afyon Kocatepe Üniversitesi İktisadi ve İdari Bilimler Fakültesi Dergisi, 10(1).

BELK P.E. VE GLAUM M., (2012) "The Management of Foreign Exchange Risk in UK Multinationals: An Empirical Investigation”, Accounting and Business Research, 21, s.3-13.

BOLAK M., (2004), Risk Yönetimi, Birsen Yayınevi, İstanbul, 2004.

BOLGÜN E., (2002) “Ticari Bankalarda RMD Yöntemiyle Ölçülen Piyasa Riskinin Bankacılık Stratejilerine Etkisi”, Doktora Tezi, Marmara Üniversitesi Bankacılık ve Sigortacılık Enstitüsü, İstanbul.

BOLGUN E. VE AKÇAY B., (2005) “Risk Yönetimi”, Scala Yayıncılık, 2. Baskı, İstanbul.

BROOKS C. (2008), "Introductory Econometrics for Finance” Cambridge University Press, New York.

BUĞRA A., (2003) “İktisatçılar ve İnsanlar”, İletişim Yayınları, İstanbul, 2003.

BUTLER Cormac, (1999), "Mastering Value at Risk: A Step-By-Step Guide to Understanding and Applying VaR”, Financial Times/Prentice Hall.

ÇATAL D., and ALBAYRAK, R.S., (2013) "Riske Maruz Değer Hesabında Karışım Kopula Kullanımı: DolarEuro Portföyü”, Journal of Yaşar University, 8(31), s.5187-5202.

ÇELİK, S, KAYA, F. (2019). Banka Karlılığına Etki Eden Mikro Değişkenler: Türk Bankacılık Sektörü Üzerine Bir Araştırma. Bolu Abant İzzet Baysal Üniversitesi Sosyal Bilimler Enstitüsü Dergisi, 19 (3), 765-788. DOI: 10.11616/basbed.v19i49542.594328

ÇELİK, S. (2019) “Credit Policy in Banking Sector”, Turkey's Economic, Fiscal and Social Problems, (Ed: Akınc1, A.; Özçelik, Ö.), Ekin Yayınevi. Bursa, 63-74.

ÇELIK, S. (2019) “Credits and Credit Analysis in Banking Sector”, Interdisciplinary Public Finance, Business and Economics Studies Volume II, (Ed: Akınc1, A.; Özçelik, Ö.), Peterlang GMBH. Berlin, 151-160.

ÇELİK N., (2010), “Uç Değerler Yöntemi İle Riske Maruz Değer'in Tahmini ce İstanbul Menkul Kıymetler Borsası Üzerine Bir Uygulama”, Bankacılık ve Sigortacılık Araştırmaları Dergisi, 1(1), s.19-32.

ÇIÇEK M. ve ÖZTÜRK F., (2007), "Yabancı Hisse Senedi Yatırımcıları Türkiye Döviz Kuru Volatilitesini Şiddetlendiriyor Mu?”, Ankara Üniversitesi SBF Dergisi, 62(4), s.83-107.

ÇONKAR M.K. ve VERGİLİ, G., "Kredi Temerrüt Swapları ile Döviz Kurları Arasındaki Nedensellik İlişkisi: Türkiye İçin Ampirik Bir Analiz”, Ömer Halisdemir Üniversitesi İktisadi ve İdari Bilimler Dergisi, 10(4), s.5966. 
DEMIRAG İ. ve GODDARD S., (1995) "Financial Management for International Business", McGraq-Hill, England.

DEMİRELİ E. ve TANER, B., (2009) "Risk Yönetiminde Riske Maruz Değer Yöntemleri ve Bir Uygulama", Süleyman Demirel Üniversitesi İktisadi ve İdari Bilimler Fakültesi Dergisi, 14(3), s.127-148.

DOĞANAY M., (2016), “Döviz Kuru Riski Yönetiminde Sektörel Bir Yaklaşım”, International Journal of Cultural and Social Studies, s.2, s. 49-164.

DUMAN M., (2000), "Bankacılık Sektöründe Finansal Riskin Ölçülmesi ve Gözetiminde Yeni Bir Yaklaşım: Value at Risk Metodolojisi”, Bankacılar Dergisi, 30, s.22-30.

EMHAN A., (2009), “Risk Yönetim Süreci ve Risk Yönetmekte Kullanılan Teknikler”, Atatürk Üniversitesi İktisadi ve İdari Bilimler Dergisi, 2(23), s. 209-220.

ERGÜL N. (2004), Herkes İçin Finans, 1. Basım, Literatür Yayıncılık, İstanbul,.

ESER Ö., (2010), "Piyasa Riski Ölçümü Olarak Riske Maruz Değer ve Hisse Senedi Portföyleri İçin Bir Uygulama”, Yüksek Lisans Tezi, Kadir Has Üniversitesi Sosyal Bilimler Enstitüsü, İstanbul.

GÜNEŞ Ş. (2009), Kurumsal Risk Yönetimi ve Türkiye'de Farkındalı̆̆ına İlişkin Bir Uygulama, Yüksek Lisans Tezi, İstanbul Teknik Üniversitesi Fen Bilimleri Enstitüsü, İstanbul.

GÜRSAKAL S., (2007) "IMKB 30 Endeksi Getiri Serisinin Riske Maruz Değerlerinin Tarihi Simülasyon ve Varyans Kovaryans Yöntemleri İle Hesaplanması”, 8. Türkiye Ekonometri ve İstatistik Kongresi, 24-25 Mayıs, İnönü Üniversitesi, Malatya.

İRS İ.C., (2017), Döviz Piyasalarında Piyasa Riskinin Ölçülmesi: Riske Maruz Değer Yöntemi İle Bir Uygulama, Yüksek Lisans Tezi, Dokuz Eylül Üniversitesi Sosyal Bilimler Enstitüsü, İzmir.

JACQUE L.L., (1983) "Measurement of Foreign Exchange Risk: A Review Article", International Accounting and Transnational Decisions, s. 361-384.

KANAS A., AND KOURETOS, G.P., (2001) "Black and Official Exchange Rare Volatility and Foreign Exchange Controls: Evidence From Greece”, International Journal of Finance and Economics, 6(1), s.13-25.

KAYAHAN C., VE TOPAL Y., (2009), “Tarihsel Riske Maruz Değer (RMD) Finansal Riskleri Açıklamada Yeterli Midir ?”, Süleyman Demirel Üniversitesi İktisadi ve İdari Bilimler Fakültesi Dergisi, 14(1), s.179-198.

ÖNCÜ M.A., ve ÇÖMLEKÇİ, İ., YAZGAN, H.;., VE BAR, (2015), “Yatırım Araçları Arasındaki Eşbütünleşme (Bist 100, Altın, Reel Döviz Kuru)”, AİBÜ Sosyal Bilimler Enstitüsü Dergisi, 2015, 15(1), s. 43-57.

POPOV V., AND STUTZMANN Y., (2003), "How is Foreign Exchange Managed: An Empirical Study Applied to Two Swiss Companies", University of Lausanne, http://www.hec.unil.ch/cms_mbf /master_thesis/0314.pdf (12.06.2006).

SAYILGAN G., (1995), “Finansal Risk Yönetimi”, Ankara Üniversitesi SBF Dergisi, 50(1), s. 323-334.

TAŞ O. ve ÇİTFÇí S., (2005), Bankacılıkta Piyasa Riski Yönetimi ve Bir Alım/satım Portföyü için RMD Ölçümleri, bsy.marmara.edu.tr/TR/konferanslar/2005/2005tebligleri/16.doc (17.10.2006).

URAL M., ve ADAKALE, T., (2009) “Beklenen Kayıp Yöntemi İle Riske Maruz Değer Analizi”, 2009, Akdeniz Üniversitesi İktisadi ve İdari Bilimler Fakültesi Dergisi, 9(17), s.23-29.

YILDIRIM H., VE ÇOLAKYAN, A., (2014) “Finansal Yatırım Araçlarında Riske Maruz Değer Uygulaması”, Dokuz Eylül Üniversitesi İktisadi ve İdari Bilimler Fakültesi Dergisi, 29(1), s. 1-24.

YÜCEL T., MANDACI, P.E., KURT, G., (2007) “İşletmelerin Finansal Risk Yönetimi ve Türev Ürün Kullanımı: İMKB 100 Endeksinde Yer Alan İşletmelerde Bir Uygulama”, MUFAD Journal, S.36, s.106-113. 